\title{
POSTER FOR THE SOFT CITY
}

\author{
VITTORIA CRISOSTOMI \\ Dipartimento Architettura, Università Roma 3, Italy
}

\begin{abstract}
Climate change and its effects call for concrete concern about how cities should reorganize themselves. Cities today are already vastly different from what we have learned in the manuals for lifestyles, production, and ways of living. Urban planning must revise its foundations according to the options of reduced emissions, renewable energy, circular economy and zero land consumption. It will therefore have to take a different method of mixing up the addendums of policies for cities. Instead of a complete theoretical treatment, it is necessary to grasp the faint signals scattered in the organization of the city, consolidating in new paradigms that are defined and simultaneously experienced. The experiment could concern the formation of a new profile for the city of Rome, in view of the election of the new Mayor in 2021, whose points could define a "Poster for the Soft City" in which the elements of planning are revisited in the light of new values and applied to the true city of today. The protection of the environment must be practiced with projects accompanying the needs of nature and the morphology of the places. The size of the public works is strictly in line with needs and the projects commensurate with them. Network engineering models for mobility are reviewed as an urban service to people, attentive to user behavior. The green areas which were once given up as standard, never equipped and abandoned, become the system of green networks and soft mobility rebuilding where possible the ecological continuity, according to a new landscape that keeps the original morphology together with the necessary new transformations. Entrepreneurs will also have to change and become administrators of the existing annuity, inventors and recipients of additional marginal annuity based on the improvement of settlement quality, committing themselves to management quotas and improvement of the surrounding public space.
\end{abstract}

Keywords: urban policies, new city planning, systemic approach, urban development, well-being city, soft city, annuity.

\section{URBAN INNOVATION IS AN EMERGENCY}

It is clear that the epochal climate change, the events that follow, partly catastrophic, and in part slowly enveloping, are highlighted in these days by the recurrence of cyclical epidemics and pandemics.

In parallel, although they continue to replicate in a fake presence, uninterrupted and reassuring, the rules that govern the organization of cities have also changed profoundly, the result of structural changes that have crossed all functions, all social groups and all rules of aggregation.

The cities worked and transformed up to now are the extreme result of a theory which has in the center the work of the man and the transformations brought to the biosphere, considered interventions and improvement always and however salvific, in a process of continuous growth called progress [1].

The limitations of this process had already been highlighted in the early 1970s by the theories and experiences of McHarg. He had recalled the knowledge of the ecological cycles and their causal connections that form an organized system. That is basis of the plan according to the rules of nature and defining the anthropogenic uses and the intensity of the possible transformations [2].

This line of thought called "ecological planning" has rebounded for some time in the world of urban studies also in Italy [3]-[6]. 
However, in the 1980s the core of the discipline was the pursuit of flexibility of plans and the uninterrupted push towards expansion, despite the growing awareness of the necessary respect for ecological cycles and landscapes [7]. Therefore the cultural thrust of ecological planning has been diverted towards the normative aspects of the discipline. Non-systemic supporting tools allowed elementary and simplified representations of complex problems, which could be matched by equally elementary solutions.

Despite everything, catastrophes and disruptions generated by the force of nature continue, disasters that are generated by thoughtless human transformations stratified over time, new unstoppable cycles of transformation of cities. The lack of utility and effectiveness of such simplifiers and automatic systems is apparent. These systems do not enter in the processes and reduce the actions of defense and protection in elementary connections stimulus.

\section{A CHANGE OF METHOD IS ESSENTIAL}

Therefore, it is not just a question of adapting to a new climate, of restoring degraded situations, of futuristic technological projects. Instead, we need a structural revision of the sense that cities have taken, of the new organizational rules of their vitality, of the reasons that establish their evolution [8]. In this context, it would be good to immediately worry about how cities should accompany new patterns of consumption, new ways of producing and trading, new ways of asking for mobility and relationships, new ways of asking for welfare and new ways of farming. There is a lack of real awareness of the new ways of evolving the city, already much more than what we have learned about in manuals, starting with borders. Even more different with the current Covid 19.

New forms of diagnosis of ongoing processes in cities must be matched by appropriate urban and planning discipline that is not satisfactorily reflected in traditional tools and practices. Moreover, we cannot wait for solutions resulting from global rebalances and policies; instead, the consequences are imminent and already clear. What is needed to make the measures of reconstitution and defense close and real is to immediately build a new profile of discipline that takes on a different way of mixing the addendums of policies for cities. Together with the organization of the city we must keep in mind the main options of a new system with reduced emissions, renewable energy, circular economy and zero land consumption [9].

However, you cannot expect all these new processes to be organized and packaged somewhere, structured in a system and disseminated and practiced. Instead, it is necessary to grasp the small faint signals scattered in the organization of the city, in the stratifications of its history and in the roots of social issues. Trying to consolidate, for parts even nonsystematic ones, in new paradigms that are defined and tested at the same time, before and instead of a complete theoretical treatment. Moreover, it is necessary to seek, with the usual method of trial and error, the real opportunities for experimentation [10].

An experiment may involve restarting and forming a new profile for the city of Rome, today waiting for a change in urban policy that could be redefined during the elections of the new Mayor in 2021.

The problems that always remain are those that are well-known but still unresolved, common to all metropolitan cities, each with a coloring linked to specific territorial and institutional conditions. Inefficient mobility, poor quality of general settlement, inequalities, faded development profile, interrupted works, these being still present show that they cannot be compensated with the answers given so far.

The two traditional routes are clearly not appropriate. The construction of prospects for development and growth through the armament of large projects and major works, often 
interrupted, whose lack of positive repercussions were measured. Or the list by axes or sectoral guidelines of things to do, mixing local-scale topics with urban-scale performance, wasting intelligence and money on disconnected and ineffective actions.

The solution does not lie in disciplinary instruments or technologies. It is clear that we must exert a change of vision on the nature of the city and not only on the instruments, a change of conduct of actions and not only of the review of the regulatory system. The paradigms of a re-founded urbanism become understandable and close to reality if they are based on a redefinition and reinterpretation of complex relationships that cross the problems of all time, on a correct integrated and innovative use of what there is [11].

The pillars of this necessary new way of representing problems are already written in the history of policies for cities since the late 1990s. Until the early 1990s, policies were geared to growth, and town planning was geared to orderly development of inhabited areas. After the neoliberal attempts and the obvious recession, the limits of linear growth and sectoral planning practices have become evident. Those attempts have become insufficient both to guide globalized development and to contain local conflicts. Policies will have to regulate the pursuit of profit and economic development even without physical growth, which will exalt the functional assets and the basic activities of the cities with which they enter into international competition. They will also have to regulate the containment of the selective effects of development and disparities, which will feed the search for redistributive and equitable forms of wealth. The two aspects come together producing a generalized demand for well-being and quality of settlement. For both, urban planning, in the form of the city, will have to recompose profits and work, environmental quality and social cohesion. In short, economic well-being and quality of life [12].

At this point discipline must assume the entire city is a single complex system, to ensure performance for all citizens of a overlaid and always conflicting reality. Interests, behavior, social groups, cultures, needs, are strongly integrated and, even if they can be typified, require differentiated policies and specific design treatments [13]

A new method will have to propose a vision of competitiveness, sustainability and closeness to needs. One must experience a city equal to the existing one, but "other than itself" whose points could define a "soft city poster". It will not only be the smart one permeated by new organizational technologies [14], not yet the augmented one to be fully devised in a vision of the future [15], but some first concrete seeds of practice, within the immediate reach of the available tools, for a city re-founded on commensurate projects.

In the first trials, the construction of well-being can begin by the search and identification of the necessary performances. Every sustainable intervention in the city means that it is in balance with the forms of the territory, with what it produces, with those who live in it, with those who use it and how it evolves. The city must become a resilient welcoming and productive place, with a solid basic economy, not based on tourism bite and escape nor on the all-encompassing presence of the Vatican.

Vision and realism are composed relying on the feeble and dispersed vectors of possible innovation already underway. A new policy for the city must be founded, played entirely on the level of value, on the new way of being a city and on the specific way of enhancing its essence.

\section{A SOFT CITY POSTER}

Here is a possible list of old problems to look at, and then solve, with new eyes. Here is a possible "Manifesto for the soft city" according to three main dimensions: environmental dimension, settlement dimension, economic dimension. 


\subsection{From undeveloped islands to continuous systems}

It is necessary to abandon the defense of the environment as a stiffening to any transformation and the protection of existing through inhibitory constraints. The projects must follow the reasons of the nature and morphology of the places, where to recompose and allow the present life cycles and awareness of the limits. There is an evident determinism, of the limits of the possible transformations for those who know how to read the rules of the places and match them with the needs of men.

This concretely means that the problem of the inhospitable green areas is actually that of the unperceived open spaces and this must be addressed by the reading of the primary form of city's soil, attributing meaning to all free spaces. The free areas between the built-up areas, green areas yielded in urban conventions never equipped and left abandoned, areas waiting for destinies in the interstices between neighborhoods, wrecks of intermittent waterways, areas unbuildable for intrinsic characteristics, these have to be reinserted in the continuous system of nature and its rules, that has housed the built-up areas and is often hidden from it. What is needed is the reconnection of a unitary configuration that infiltrates the built up areas, in which the parts assume a current sense. What we are going to need is a proper use of the outcrops of a continuous system, an enhancement of the green porosity made visible and accessible to citizens as soon as they leave their homes, just like the sidewalk. We need to move in a design of green networks and soft mobility reconstructing ecological continuity where it is possible, now fundamental post Covid 19.

The city that is already there must be inserted in a new understandable landscape, which holds together the original landscape brought back into everyday life, the existing city and the necessary transformations.

\subsection{From additions to rearticulating of the settlement system}

Urban growth with the simple rules of occupation of the soil according to successive additions is not a simple problem of market, in fact, it is a rigid method, more and more out of the cycle of life of the city. In concrete terms it means that the life cycle and the needs of the citizens must be accompanied with forms of technological reviews of the building and densification for the optimization of the public equipment. Forms of integration between built-up city districts must be found, filling the porosity of low density that does not use the city thoroughly according to the margins offered by nature [16].

It is necessary to soften the construction offer for new demographic forms and new types of families such as individuals, the elderly, students and young couples. The same applies to new forms of production, which can often be identified as infiltration of new functions with little space consumption [17].

It is necessary to soften the production of public works, governing its impact dimensions and positive repercussions proportionate to the problem. From large-scale new projects to projects that are tailored to needs, with projects tailored to them in techniques, costs and maintenance modes [18].

From stiffened traffic in the construction of the network engineering model to a very unlikely Fordist city, it is necessary to shape mobility as a service to people and think of relationships as value-creating city functions. From offering standard transport services to offering accessibility to urban benefits by local systems. It is not necessary to connect nodes of the network, but places of the people. It involves care of the connections and order of the networks, attention to the fluidity of the entire cycle of journey between local and urban and adequate response to the utility function of the user [19]. 


\subsection{From absolute annuity to optimization of market factors}

The system of traditional enterprises of serial building production has accumulated enough unsold produce to begin to consider a system change. From administrators of the existing annuity and its rigid organized and systematic maintenance, to inventors and receivers of additional marginal annuity based on the improvement of the settlement quality. Additional externalities can be captured not only by the overhauling and completing the building stock, but also committing to maintenance quotas management and improvement of the surrounding public space. It has been shown that the re-entry of these externalities can increase the value of the sold produce by at least 5\% [20]. In this case, it is clear that the public operator will also have to soften the imperative style towards a proactive and negotiating profile accompanying the process [21].

It should be noted that growth is damaged by inequalities. Welfare services will have to take care of the local social profile on the part of citizens. Will have soften the responses by offering more articulated local ways of living, revisiting the existing public spaces in the neighborhood that support everyday life [22].

\section{PROSPECTS FOR DEVELOPMENT}

These criteria and values of the soft, well-being city must also be applied to development. In order to be alive and constantly changing and in order to have an international role, Rome must not limit itself to offering quality of life to the settled population and an efficient functioning. It must have precise prospects of growth and development in the sectors repeatedly mentioned which, together with the functions of Capital, constitute the economic basis. These must be accompanied by plans for structural changes for adaptation and its new profile.

We cannot deny the presence of real estate developers and the necessary operations to be carried out to innovate the image of the political functions of Capital and Finance present in Rome. We cannot deny that tourism, related to the demand for leisure time and cultural enjoyment, has an important future, even if the paradigms by which it is practiced are to be reviewed completely. It is established that the film and audiovisual industry is in full revival in Italy and it is necessary to strengthen the innovative forms with which it faces the international market. Quietly, with widespread localizations and peripherals of small businesses, Rome is becoming a hub of technology and start-up experimentation, which needs to be given the right business image and a package of services and appropriate infrastructure. Universities and the system of connected research, although solid, need a strengthening of image and important places of self-representation.

Then the guide in the choice of the most important transformations will have to be to select among the projects, widely existing, and the most useful for the development of the driving activities. They will be subjected to the revision according to the new method of the city with the best settlement quality, of the city ductile and looked with a new system of values, of a "soft city" able to hold together many factors in balance.

The criterion of the soft city has a center and two connected processes: that of the settlement quality of integrated neighborhoods and the flow of daily life, and that of urban projects for the new development of the city. They are two networks of relationships of interests of aspirations of behaviors that support each other and connect in some special places.

This construction of soft urban planning for Rome seems indispensable to refund the cohesion of the city on a value of substance: values are not abstract but guide actions and have concrete economic and social fallout. Only in this way does it seems possible for urban 
planning to undertake a shared review of the profile of the city and, starting from the principle of identification and respect for the primary urban form, outline its programmatic features and the future.

\section{REFERENCES}

[1] Pellegrino, G. \& Di Paola M., Nell'Antropocene, Etica e Politica alla Fine di un Mondo Derive Approdi: Rome, 2018

[2] McHarg, I.L., Design with Nature, Falcon Press, Philadelphia, 1971.

[3] UNESCO, MAB 11 Man and the Biosphere, 1971.

[4] Giacomini, V., La Rivoluzione Tolemaica, La Scuola: Brescia, 1983.

[5] Romani, V., Il Paesaggio. Teoria e Pianificazione, F.Angeli: Milan, 1994.

[6] Tricart, J. \& Kilian, J., Ecogeografia e Pianificazione dell' Ambiente Naturale, F.Angeli: Milan, 1985.

[7] Tutino, A., L'Efficacia del Piano EL Roma, 1986.

[8] Ricci, M., La città nell'eterno presente Cambiamenti dell'Urbanistica Donzelli, Rome, 2017.

[9] Talia, M., Storia, Passione, Competenza: tre Parole Guida per una Nuova Stagione Urbanistica. Urbanistica, 161, 2018.

[10] Secchi, B., Per un'agenda urbana e territoriale. Città tra Sviluppo e Declino, Donzelli: Rome, 2014.

[11] Carta, M., Futuro. Politiche per un Diverso Presente Rubbettino: Palermo, 2019.

[12] Calafati, A.G., La costruzione dell'agenda urbana europea e italiana. Città tra Sviluppo e Declino, Donzelli: Rome, 2014.

[13] Carta, M., Reimagining Urbanism, ListLab: Trento, pp. 131-147, 2014.

[14] Cristoforetti, G., Smart Cities and Community-Based Planning, INUedizioni, 2014.

[15] Carta, M., Augmented Cities, A Paradigm Shift Babel Theory, 2017.

[16] Lanzani, A., Per una politica nazionale delle città e del territorio. Città tra Sviluppo e Declino, Donzelli: Rome, 2014.

[17] Annunziata, S., A quale titolo (di godimento)? Note per una politica della casa in prospettiva post crisi. Città tra Sviluppo e Declino, Donzelli: Rome, 2014.

[18] Ferrante, A., Efficienza nei lavori pubblici DEI, Rome, 2017.

[19] Crisostomi, V., Infrastrutture e spazio metropolitano. Il caso di Roma. Ordinamenti Spaziali e Infrastrutture, Aracne: Rome, 2016.

[20] Ferrini, F., Valori immobiliari, spazi verdi e salute pubblica. Presented at Urbanpromo - Green Venezia, Italy, 2019.

[21] Curti, F., Lo Scambio Leale, Negoziazione Urbanistica e Offerta Privata di Spazi e Servizi Pubblici Officina: Rome, 2006.

[22] Sim, D., Soft City, Island Press: Washington DC, 2019. 